\title{
A Study of Indian Copper Market in Multi-Commodity Exchange
}

\author{
R. Sushma, B. N. Shubha \\ Department of Management, Studies \& Research Centre, B.M.S.C.E, Bangalore, Karnataka, India \\ Email: rsushma.mba@bmsce.ac.in, bns.mba@bmsce.ac.in
}

How to cite this paper: Sushma, R., \& Shubha, B. N. (2022). A Study of Indian Copper Market in Multi-Commodity Exchange. Modern Economy, 13, 37-50. https://doi.org/10.4236/me.2022.131003

Received: December 9, 2021

Accepted: January 15, 2022

Published: January 18, 2022

Copyright $\odot 2022$ by author(s) and Scientific Research Publishing Inc. This work is licensed under the Creative Commons Attribution International License (CC BY 4.0).

http://creativecommons.org/licenses/by/4.0/

\begin{abstract}
This paper examines the relationship between spot and futures prices in the Indian commodity market from 2015-2019, considering copper as one of the base metals. In this study, the closing spot and future price data obtained from Multi commodity exchange of India are used to investigate price discovery. Various econometric tools are used to explore the long and the short-run relationship between spot and futures prices. ADF, Johansen's and Juliesus cointegration test, Vector Error Correction Model Test, Granger causality is carried out during the empirical process. The statistical result of the study indicates that the price is first discovered in the spot market for copper during the study period. The granger causality test indicates that it is unidirectional in the short run.
\end{abstract}

\section{Keywords}

G1: Commodity Market, Base Metal, Price Discovery

\section{Introduction}

The efficient market price of the assets will adjust rapidly to new information (Fama, 1970). Consequently, if future and spot prices are perfectly efficient, all relevant information would immediately be utilised by the players in the market to determine the price of related assets. Future prices move in tandem with the price of its underlying assets and, the market information is reflected simultaneously without any leading or lagging movement in one another (Debasish, 2009). This indicates that there is no arbitrage or speculation process (Wahab \& lashgari, 1993; Kavussanos \& Alexakis, 2008). However, the markets are inefficient due to market resistance factors such as trading cost, infrequent trading, short sale restrictions, etc. Hence there exists a lead-lag relationship between two 
prices.

This research aims at understanding the extent to which the Indian commodity market is efficient. The literature explaining price discovery is not new. However, India is an emerging market, and the exchange offers the best commodities like crude oil, non-agricultural commodities, base metals, precious metals, agricultural commodities like turmeric, wheat etc. To trade in India, finding the equilibrium price that facilitates liquidity for that asset is necessary. This study uses copper as the commodity for the investigation since base metal markets are more volatile in nature and it has an impact on the economy. The base metal commodity copper is used for commercial purposes as they constitute inputs for many industries. Copper occupies third position in world metal consumption after steel and aluminium. Copper trading reflects the state of the economy, and it is a highly tradable commodity. This metal has gained more traction as an investment option, and players protect or exploit future price movements and hence copper is considered for price discovery in this study. This study also aims at understanding the efficient market.

Numerous studies have explored the price discovery process in various markets. Most of the studies that originated from developed economies indicate future markets play a critical role in price discovery for underlying spot markets (Darrat, 2002; Tse, 2000; Lehmann, 2002; Quan, 1992; Stroll \& Whaley, 1990; Schreiber \& Schwartz, 1986; Garbade \& Silber, 1983). While studies from emerging economies have also found that future leads spot market (Debasish \& Mishra, 2008; Rajib \& Barai, 2021; Nath et al., 2019; Kirithiga et al., 2018; Narayan \& Sharma, 2018; Kumar, 2017; Inani, 2016). To help better understand the price discovery process in an emerging economy, this study aims to carry out an empirical analysis on copper futures and spot prices considering four years of data from 2015-19. Since copper is the most actively traded futures contract used in a variety of application that is necessary for the standard of living and consumed by end-users. Hence price discovery becomes important both in the domestic and international markets along with understanding the speed of information flow from one market to another.

It is observed that there are not many researches carried out in price discovery specific to copper base metal hence this study aims to present a means to arrive at the price discovery process. The outcome of the study may interest academicians, investors and other participants interested in the financial market development. The outcome may also help researchers aiming to study other base metals in Indian market and other international market.

The remainder of this paper is organised as follows: a comprehensive literature review is presented in Section 2, the analytical framework is discussed in Section 3, econometric analysis and empirical results are discussed in Section 4 and the conclusion in Section 5.

\section{Literature Review}

The research paper of (Rajib \& Barai, 2021) is an empirical study and sur- 
vey-based analyses showing price discovery as the fundamental value of physical prices and facilitating price risk transfer. The participants in the commodity market wish to take risks in exchange for a return. In the commodity markets, the contracts are fine-tuned by exchanges to meet the requirements of participants. The compulsory delivery for few base metals necessitates a study to explore the market. The research indicates that future price takes information first and passes it to the spot market. The speed of information transfer between the markets has improved significantly after the contract act modification in March 2019. (Nath et al., 2019), study the effectiveness and price discovery in the Indian gold futures market. The information was gathered from January 2008 to March 2018. This research aimed to investigate the microstructure of the Indian gold market and policy changes on the Indian gold market. Across numerous political regimes, the study experimentally checks for gold futures efficient markets and determines the flow of information between the spot and futures markets. The author observed a long run cointegration relationship between future and domestic spot markets. The daily price discovery occurs in the futures market, although not in the spot market. The risk of any assets is ascertained by volatility. To understand the risk concerns of gold and silver, various studies in the Indian commodity market were carried on. (Kirithiga et al., 2018), has examined the role of volatility in determining the bullion price by using daily spot and the future price of all gold and silver contracts available at MCX for a period of ten years from 2006 to 2015. The author has found that the previous day's return information affects today's return volatility and spot prices collect information from futures prices. (Gupta et al., 2018) study indicates long-term economic efficiency and price discovery in the Indian commodity futures market. Two agricultural commodities, two industrial commodities, two precious metals, and two energy commodities were considered for the research. The spot and futures market time series was considered for the study using advanced statistical approaches such as restricted cointegration and the vector error correction model (VECM). The outcome of the study indicates Indian commodity futures market is inefficient and biased in the long term and thus fails to predict future spot prices. Further, the study also indicates the lag value of both spot and future price through autoregression, which reaffirms future markets' inefficiency. While (Narayan \& Sharma, 2018) recommend a model for time-varying price discovery based on the rolling framework and found that spot market leads in price discovery for nine commodities and the other six commodities are dominated by future markets. They also showed the economic importance of price discovery through portfolio construction and hedging strategy. The study of (Kumar, 2017) price discovery in the context of Indian commodity market indicates strong causation extending from futures to spot prices using daily price data for nine crops from 2009 to 2014. The result indicates that future prices would help farmers make more efficient decisions. Furthermore, it would enable them to maximise earnings by determining whether to keep or sell their output at any time, 
based on futures pricing data. (Inani, 2016) study price discovery of Indian commodity market using common factor model where the researcher has considered combined commodity index, metal index, energy index and agricultural index closing price from 21 October 2005 to 29 May 2015. VECM is estimated, and spot and future indices are cointegrated except the agricultural index. It was also indicated that for composite and metal indexes, price discovery happens in the spot market, whereas the energy index happens in the future market. (Sinha \& Mathur, 2013) the study aims at the price behaviour of five base metals on MCX using near month of future contracts from 2007 to 2013. Impact of global crisis was examined using GARCH Model. The paper suggests, introduction of option base metals in the Indian commodity market. (Pindyck, 2004) examines the short-run dynamics of commodity prices and inventories, concentrating on the behaviour and volatility. The model was developed considering spot and future price, accounting for volatility. While (Engle, 1982) examined autoregressive conditional heteroscedasticity ( $\mathrm{ARCH}$ ) where the past conditional variances in the current conditional variance equation are proposed. For the new parametric model, stationarity and autocorrelation structure is derived. Maximum likelihood is considered. The model is used to estimate the means and variances of inflation in U.K. (Garbade \& Silber, 1983). Two of the most important contributions of future markets to the organisation of economic activity are risk transfer and price discovery. Price movement characteristics in the cash and futures markets for storable commodities-wheat, corn, oats, gold, copper, silver of New York Stock exchange are examined with the lead-lag relationship. The study highlights futures market leads the cash market; cash prices do not simply reflect futures prices. They also argued that the elasticity of supply for arbitrage services is constrained by storage and transaction costs. However, it is the time lag that impacts the degree of integration. They found liquidity and the size of the market helpful in the price discovery process.

Based on the previous literature review it is observed that developed and emerging markets exhibits mixed outcome in different commodities (agricultural, precious metal and base metals). This indicates that spot market lead future market in some instances while it is the reverse in few other instances. These reviews framed the basis for identifying the spot market price and futures market price as the variables for the research study.

\section{Research Methods}

This section discusses the analytical framework of price discovery, data sources, variables, and the econometric model. In order to further progress with the analysis the variables are converted for natural logarithms.

\subsection{Cost of Carrying Model}

Theoretically, the relationship between two prices, future, and spot of an underlying asset, leads to the cost of the carry model denoted as below. 


$$
F_{t}=S_{t}+(r-d)
$$

where $F_{t}$ is the futures price at time $t, S_{t}$ is the spot price at time $t, r$ is the risk-free rate of return, $d$ is the dividend yield, and $t$ is the maturity date of the futures contract.

\subsection{Descriptive Statistics}

The research is descriptive in nature. It is to be noted that logarithmic transformation of variables is done to minimise heteroscedastic nature. $\mathrm{R}$ software is used for econometric analysis, ADF, Johansen and Julius cointegration test and VECM, Granger causality test is carried out for the price discovery process.

\subsection{Model Specification}

The main objective is to examine the efficiency level of price discovery in the Indian commodity future and spot markets. According to the efficient market hypothesis, information is reflected instantly in spot and futures prices in an efficient market, which means there is no speculation or arbitrage process. This study adopts ADF as it helps to analyse autocorrelated data and helps to include lag values as per the frequency of data.

Augmented dickey Fuller Test:

$$
\Delta X_{t}=\rho_{o}+\rho X_{t-1}+\Sigma \delta_{i} \gamma \Delta X_{t-i}+\varepsilon_{t}
$$

The present study relies on the Johansen and juselius test of cointegration and vector error, as it is widely used to test cointegrating relationships for non-stationary time series data.

$$
\Delta Y_{t}=\mu+\Pi Y_{t-1}+\Sigma \Gamma \Delta Y_{t-1}+\varepsilon_{t}
$$

The paper uses the vector correction model to understand the short-run properties. Nonexistence of cointegration directly roots to Granger Causality test to ascertain causal linkage between variables.

$$
\begin{aligned}
& R_{s t}=\mu_{s}+\lambda_{1} Z_{t-1}+\sum_{i=1}^{k} \alpha_{s, i} R_{s, t-i}+\sum_{j=1}^{l} \beta_{s, j} R_{f, t-j}+\varepsilon_{s, i} \\
& R_{f t}=\mu_{f}+\lambda_{2} Z_{t-1}+\sum_{i=1}^{k} \alpha_{f, i} R_{f, t-i}+\sum_{j=1}^{l} \beta_{f, j} R_{s, t-j}+\varepsilon_{f, i}
\end{aligned}
$$

$Z_{t-1}$ is the error correction term. $\lambda_{1} Z_{t-1} \& \lambda_{2} Z_{t-1}$ speed of adjustment of return long-run equilibrium. $\alpha_{s}, \alpha_{f}, \beta_{s}, \beta_{f}$ measures short-run integration.

\section{Results and Discussion}

\subsection{Descriptive Statistics of Copper (Table 1, Graph 1, Graph 2)}

The descriptive statistic of copper indicates that the average spot is less than the average future, indicating a contango in both periods. The maximum return of copper future from 2015-2019 is 6.197 while the minimum is 5.69 with an average of 5.96. Spot returns of copper has a maximum of 6.2 and a minimum of 5.66 with an average of 5.94. The high value of standard division reveals the 
Table 1. Showing the descriptive statistics for copper.

\begin{tabular}{ccc}
\hline & Copper & \\
\hline & Spot & Future \\
\hline Mean & $5.94 \mathrm{E}+00$ & $5.96 \mathrm{E}+00$ \\
SD & 0.1412 & 0.1488 \\
Min & 5.664 & 5.692 \\
Max & 6.2 & 6.197 \\
Skew & -0.1548 & -0.32 \\
Kurtosis & -1.35 & -1.4 \\
Observations & 1248 & 1248
\end{tabular}

Source: Authors statistical calculation.

non-stability of price during both the period. The skewness of copper is harmful in both the spot and future which reveals the series is asymmetrical and left distributed based on the nature of the commodity. The analysis indicates commodities are very similar to the other set of asset's classes in the financial market.

\subsection{Stationarity of Copper Futures}

Before checking cointegration, it is essential to do unit root analysis to identify the stationarity or order of integration of price series. The copper spot price and month futures price are checked for stationarity using the Augmented Dickey-Fuller test (Table 2).

$\mathrm{H}_{0}$ : The variables have a unit root.

From Table 2, it is seen that all the series are non-stationarity consisting of a unit root. "At level test" indicates that the calculated value are more significant than the critical value. Nevertheless, by taking differences, all the series are stationary at a $1 \%$ significance level for the period. Hence, the null hypothesis is rejected.

From Table 3 it is seen that there are four significant values in lag 1 that are $6554.059,900.6896,12.47891,12.51505,12.49282$. This shows that there exists a long run relationship between spot and future price.

\subsection{Cointegration Test for Copper}

After confirming the stationarity of copper future price and spot prices, Johansen's and Juliesus cointegration test is performed to analyse the long-run equilibrium relationship between the variable (Table 4).

$\mathrm{H}_{0}$ : There is no cointegration between future and spot prices of copper.

From the cointegration test with lag 1 at $5 \%$ it is seen that the hypothesis is rejected.

Unrestricted Cointegration Rank Test (Lag Interval = 1) (Model) 
Table 2. Results of unit root test table (ADF).

\begin{tabular}{|c|c|c|c|}
\hline \multicolumn{4}{|c|}{ Null hypothesis: the variable have a unit root } \\
\hline \multicolumn{4}{|c|}{ At Level } \\
\hline & & SPOT_PRICE & FUTURE_PRICE_CONTRACT \\
\hline With & t-Statistic & -1.3182 & -1.0256 \\
\hline Constant & Probability & 0.6229 & 0.7458 \\
\hline With & t-Statistic & -2.3664 & -3.7908 \\
\hline $\begin{array}{l}\text { Constant } \\
\text { \& Trend }\end{array}$ & Probability. & 0.3971 & $0.0174^{\star *}$ \\
\hline $\begin{array}{l}\text { Without } \\
\text { Constant }\end{array}$ & t-Statistic & -0.0201 & 0.9917 \\
\hline \& Trend & Probability & 0.6759 & 0.9155 \\
\hline \multicolumn{4}{|c|}{ At First Difference } \\
\hline & & D (SPOT_PRICE) & D (FUTURE_PRICE) \\
\hline With & t-Statistic & -34.7189 & -29.3372 \\
\hline Constant & Prob. & $0^{* * *}$ & $0^{* * *}$ \\
\hline $\begin{array}{c}\text { With } \\
\text { Constant }\end{array}$ & t-Statistic & -34.7024 & -29.3349 \\
\hline \& Trend & Probability & 0 & 0 \\
\hline $\begin{array}{l}\text { Without } \\
\text { Constant }\end{array}$ & $\mathrm{t}$-Statistic & -34.7373 & -29.3111 \\
\hline \& Trend & Probability & $0^{* * *}$ & $0^{* * *}$ \\
\hline
\end{tabular}

Source: Authors Statistical Calculation. Notes: a: $\left({ }^{*}\right)$ significant at the $10 \%$; $\left({ }^{* *}\right)$ significant at the $5 \%$; $\left(^{* * *}\right)$ significant at the $1 \%$ and (no) not significant; b: lag length based on SIC; c: probability-based on MacKinnon (1996) one-sided $p$-values.

Table 3. Var lag order selection criteria.

\begin{tabular}{ccccccc}
\hline Lag & LogL & LR & FPE & AIC & SC & HQ \\
\hline 1 & -4810.861 & $6554.059^{*}$ & $900.6896^{*}$ & $12.47891^{*}$ & $12.51505^{*}$ & $12.49282^{*}$ \\
2 & -4809.22 & 3.26076 & 906.2112 & 12.48503 & 12.54525 & 12.5082 \\
3 & -4805.275 & 7.817946 & 906.3415 & 12.48517 & 12.56948 & 12.51761 \\
4 & -4801.481 & 7.500577 & 906.8251 & 12.4857 & 12.5941 & 12.52741 \\
\hline
\end{tabular}

Source: Authors statistical calculation; indicates lag order selected by the criterion; LR: sequential modified LR test statistic (each test at 5\% level); FPE: final prediction error; AIC: Akaike information criterion; SC: Schwarz information criterion; HQ: Hannan-Quinn information criterion.

Table 4. Cointegration test with lag 1 at $5 \%$ level (trace test).

\begin{tabular}{cccc}
\hline & Model 2 & Model 3 & Model 4 \\
\hline None $^{*}$ & 15.57930 & 13.51914 & $26.55081^{\star *}$ \\
At most 1 & 2.552391 & 0.709269 & 11.65442 \\
\hline
\end{tabular}

Source: Authors statistical calculation. ${ }^{\star}$ Denotes rejection of the hypothesis at the 0.05 level; ${ }^{\star *}$ MacKinnon-Haug-Michelis (1999) $p$-values. 

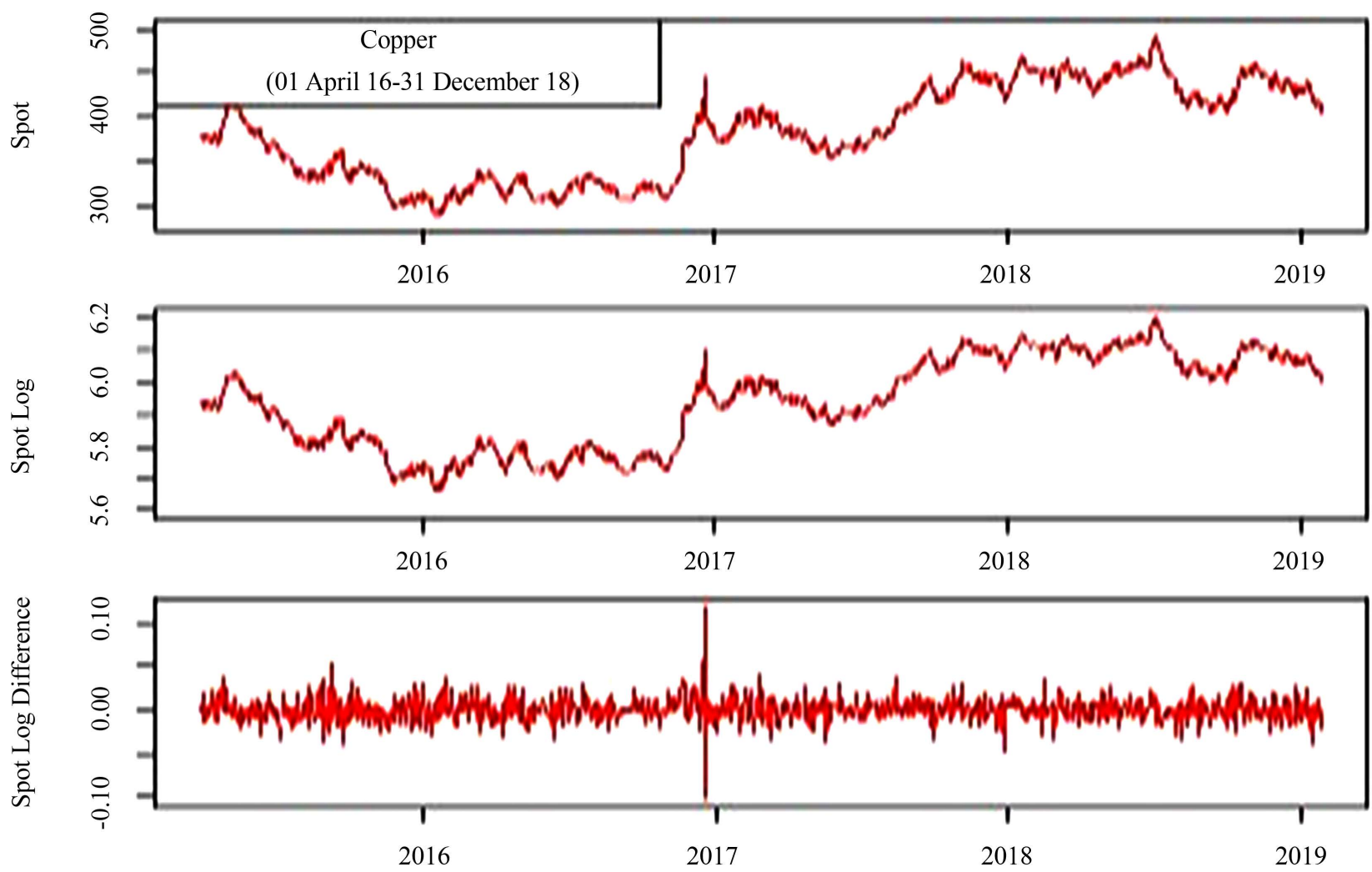

Graph 1. Trend movement of spot copper contract, https://www.mcxindia.com.
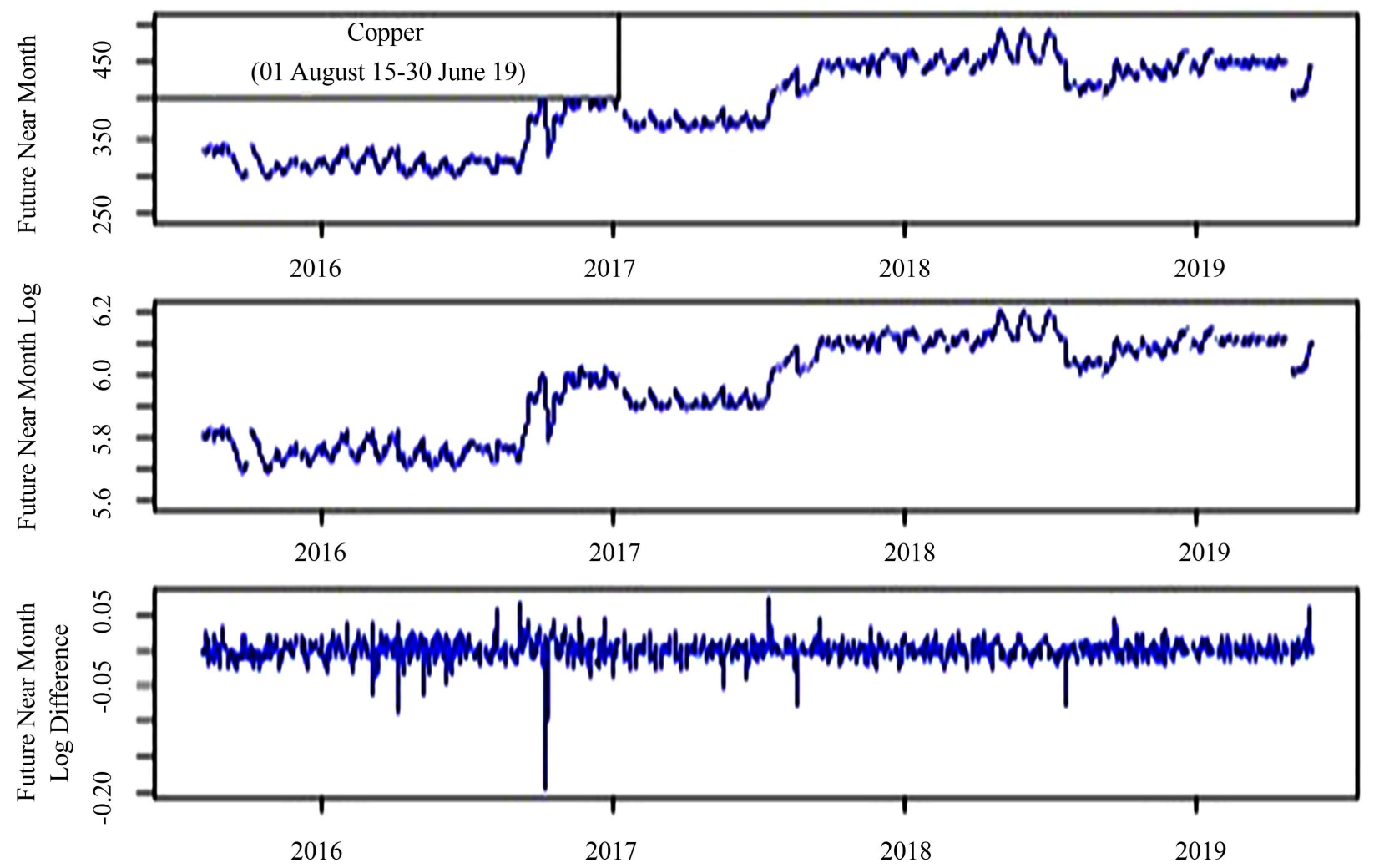

Graph 2. Trend movement of future copper contract, https://www.mcxindia.com. 
4) Copper. Intercept and Trend in CE-No Intercept in Var Sample (adjusted): 4/07/2015 12/31/2018

Included observations: 844 after adjustments

Trend assumption: Linear deterministic trend (restricted)

Series: Spot-price future-price

Lags interval (in first differences): 1 to 1

Unrestricted Cointegration Rank Test (Trace)

\begin{tabular}{ccccc}
\hline $\begin{array}{c}\text { Hypothesised } \\
\text { No. of CE(s) }\end{array}$ & Eigenvalue & Statistic & Critical Value & Probability.** \\
None ${ }^{*}$ At most 1 & 0.017495 & 26.55081 & 25.87211 & 0.0411 \\
& 0.013714 & 11.65442 & 12.51798 & 0.0694 \\
\hline
\end{tabular}

The above values indicates Trace test cointegrating equation at the 0.05 level * denotes rejection of hypothesis at the 0.05 level

${ }^{*}$ indicates the MacKinnon-Haug-Michelis (1999) $p$-values

Unrestricted Cointegration Rank Test (Maximum Eigenvalue)

\begin{tabular}{ccccc}
\hline $\begin{array}{c}\text { Hypothesised } \\
\text { No. of CE(s) }\end{array}$ & Eigenvalue & Statistic & Critical Value & Probability. $^{* *}$ \\
None ${ }^{\star}$ At most 1 & 0.017495 & 14.89638 & 19.38704 & 0.1993 \\
& 0.013714 & 11.65442 & 12.51798 & 0.0694 \\
\hline
\end{tabular}

The above Max-eigenvalue test indicates no cointegration at the 0.05 level * denotes rejection of hypothesis at the 0.05 level

**indicates the MacKinnon-Haug-Michelis (1999) $p$-values

From Table 5, the optimum lag length has been identified using the Schwarz information criterion. The result of cointegration is given in detail in the above table. Both Trace statistics and Max Eigen statistics are considered.

The results of no cointegration (None) are rejected as the trace statistics (26.55081), and Max Eigen statistics (14.89638) is more significant than the critical value of 25.87211 and 19.38704 respectively. The $H_{a}$ indicates that at most one cointegration exits in the trace statistics (11.65442) and Max Eigen statistics (11.65442) is less than the critical value of 12.51798 respectively. Therefore, $\mathrm{H}_{0}$ is rejected, and $\mathrm{H}_{\mathrm{a}}$ is accepted indicating at most, one cointegration being present

Table 5. Cointegration test with lag 2 at $5 \%$ level (trace test).

\begin{tabular}{cccc}
\hline & Model 2 & Model 3 & Model 4 \\
\hline None $^{\star}$ & $28.52647^{\star \star}$ & $27.52872^{\star \star}$ & $33.76610^{\star \star}$ \\
At most 1 & 7.897079 & $7.125843^{\star \star}$ & $13.01078^{\star \star}$ \\
\hline
\end{tabular}

Source: Authors statistical calculation. denotes rejection of the hypothesis at the 0.05 level; ${ }^{\star *}$ MacKinnon-Haug-Michelis(1999) $p$-values. 
in that period. The results of no cointegration (None) are rejected as the trace statistics (33.76610), and Max Eigen statistics (13.01078) is more significant than critical value and denote rejection of $\mathrm{H}_{0}$ at $0.05 \%$. And the presence of at most one cointegration confirmed.

The markets of copper prices move together in the given period.

\subsection{Vector Error Correction Estimation (VECM)}

After confirming Cointegration, VECM is used to analyse long-run causality.

$\mathrm{H}_{0}$ : There is no long-run causality between the near-month future and spot prices of copper.

Table 6 indicates the results of VECM (with lag two). One out of two ECT turns to be negative, and the error correction spot is negative and statistically

Table 6. Result of vector error correction estimation.

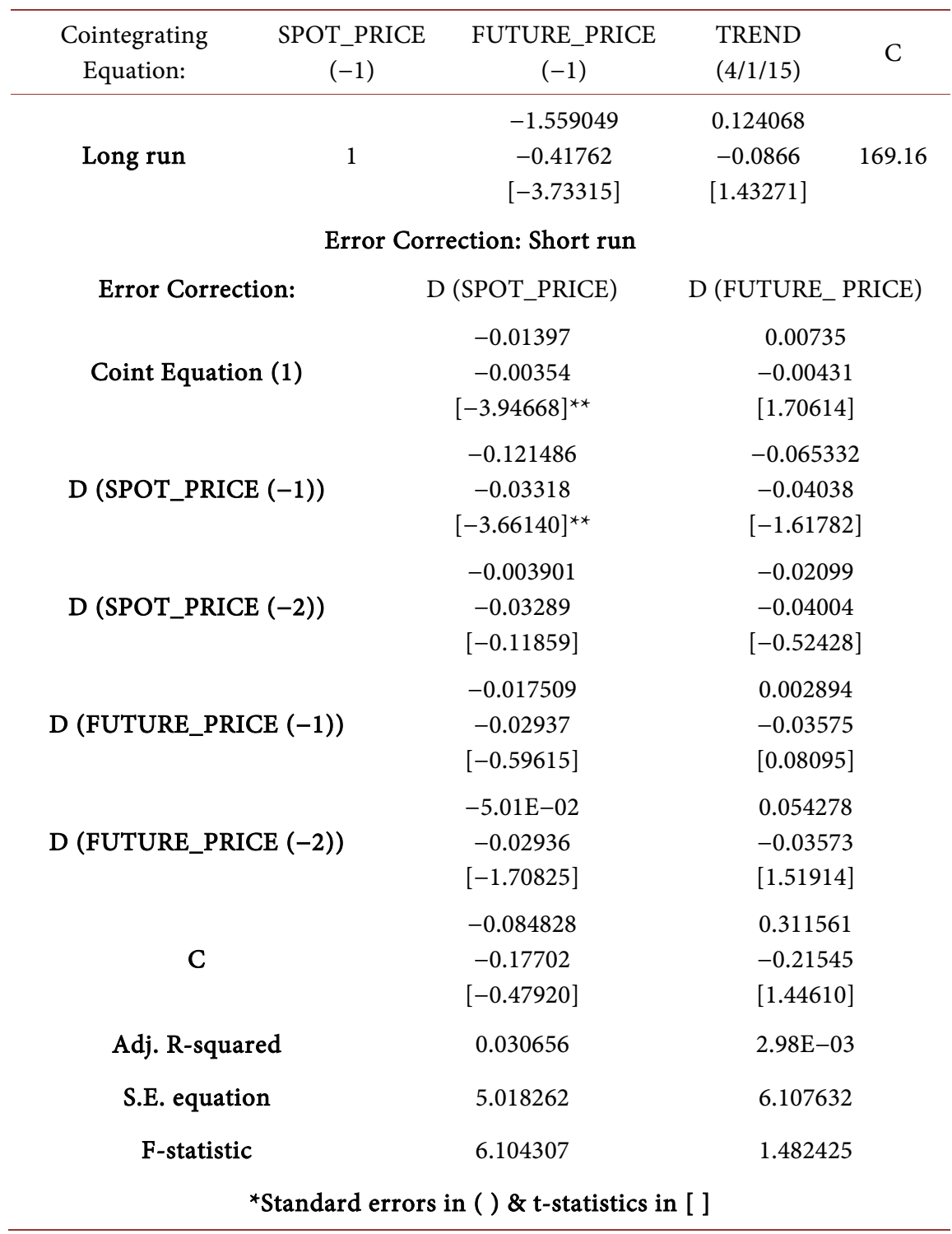

Source: Authors statistical calculation. 
significant. Hence, we conclude that spot is the leader in the long run process among two variables.

Table 7 indicates bidirectional causality short-run causality between spot and future of copper. Since the chi-square value is high in the spot price, short-run causality is more from future to spot in copper futures.

Pairwise Granger Causality Test-LAG 2

The granger causality test is applied to check the lead-lag relationship between copper futures and spot prices.

$\mathrm{H}_{0}$ : There is no lead-lag relationship between spot and futures prices of copper

Table 8 indicates that the probability of the null hypothesis is higher than 0.05 , and we accept the null hypothesis, where results shows that the past prices

Table 7. Result of diagnostics test.

\begin{tabular}{|c|c|c|c|}
\hline \multicolumn{4}{|c|}{$\begin{array}{c}\text { DIAGNOSTICS TEST } \\
\text { VEC Residual Portmanteau Tests for Autocorrelations }\end{array}$} \\
\hline Lags & \multicolumn{3}{|c|}{3} \\
\hline Q-Stat & \multicolumn{3}{|c|}{15.49692} \\
\hline Prob.* & \multicolumn{3}{|c|}{0.0301} \\
\hline Adj Q-Stat & \multicolumn{3}{|c|}{15.53912} \\
\hline Prob.* & \multicolumn{3}{|c|}{0.0297} \\
\hline Df & \multicolumn{3}{|c|}{7} \\
\hline \multicolumn{4}{|c|}{ VEC Residual Serial Correlation LM Tests } \\
\hline Lag & \multicolumn{3}{|c|}{3} \\
\hline $\mathrm{LRE}^{\star}$ stat & \multicolumn{3}{|c|}{62.64976} \\
\hline Df & \multicolumn{3}{|c|}{12} \\
\hline Prob. & \multicolumn{3}{|c|}{0.00} \\
\hline Rao F-stat & \multicolumn{3}{|c|}{5.308011} \\
\hline Df & \multicolumn{3}{|c|}{$(12,1590.0)$} \\
\hline Prob. & \multicolumn{3}{|c|}{0} \\
\hline \multicolumn{4}{|c|}{ VEC Residual Normality Tests } \\
\hline Component & SPOT_PRICE & FUTURE Price & Joint \\
\hline Jarque-Bera & 649.7518 & $18,947.54$ & $19,597.3$ \\
\hline df & 2 & 2 & 4 \\
\hline Prob. & 0.00 & 0.00 & 0.00 \\
\hline \multicolumn{4}{|c|}{ VEC Residual Heteroskedasticity Tests (Levels and Squares) } \\
\hline Dependent & SPOT_PRICE & \multicolumn{2}{|c|}{ FUTURE_PRICE } \\
\hline Chi-sq (10) & 316.8531 & \multicolumn{2}{|c|}{13.26103} \\
\hline Prob. & 0.00 & \multicolumn{2}{|c|}{0.2094} \\
\hline
\end{tabular}

Source: Authors statistical calculation. 
Table 8. Result in pairwise granger causality test.

\begin{tabular}{ccc}
\hline Null Hypothesis: & F-Statistic & Probability. \\
\hline FUTURE_PRICE does not Granger Cause SPOT_PRICE & 5.14 & 0.006 \\
SPOT_PRICE does not Granger Cause FUTURE_PRICE & 1.561 & 0.210 \\
\hline
\end{tabular}

Source: Authors statistical calculation.

cannot predict the future prices. It also indicates a unidirectional causal relationship from the future to the spot market of copper during this period. As Futures Contract does not Granger Cause Spot Price is high in value. This shows the future market dominates the future markets exists. The impact of news is first reflected in the future market, followed by the spot market.

\section{Conclusion}

This research paper examines the price discovery of the Indian commodity market using copper as the base metal. The researcher has considered daily data of closing prices of spots and futures from 2015-2019. Future research can be carried on extending the period. The study has used several econometric tests like unit root, cointegration, and vector error correction models to examine spot and futures prices. The unit root test confirmed that variables are integrated at the first difference I (1). Further, the cointegration test confirmed that copper spot and futures cointegrated at most one in the contract by indicating a long-run relationship. The causality test reveals that spot price leads to future price for copper in the long run and a bidirectional causality in the short run from future to spot for copper. It is confirmed that new information impacts the prices. Depending on external factors like monetary policy, exchange rate, interest rates, convenience yield, the prices of commodities may take contango or backwardation position. In this context it is important to check which factor will drive commodity market prices and how participants shift the market position to hedge their risk.

The present study can be supported with further research by examining more underlying assets in the commodity market and studying the impact of macroeconomic factors on the commodity market.

\section{Conflicts of Interest}

The authors declare no conflicts of interest regarding the publication of this paper.

\section{References}

Darrat, A. L. (2002). The Relative Efficiency of Interest-Free Monetary System: Some Empirical Evidence. The Quarterly Review of Economics and Finance, 42, 747-764. https://doi.org/10.1016/S1062-9769(01)00119-3

Debasish, S. S. (2009). An Econometric Analysis of the Lead-Lag Relationship between India's NSE Nifty and Its Derivative Contracts. The Journal of Risk Finance, 10, 350-364. 
https://doi.org/10.1108/15265940910980650

Debasish, S. S., \& Mishra, B. (2008). An Econometric Study of Lead-Lag Relationship between Futures and Spot Markets in India. Paradigmi, 12, 87-92. https://doi.org/10.1177/0971890720080209

Engle, R. F. (1982). Autoregressive Conditional Heteroscedasticity with Estimates of the Variance of United Kingdom Inflation. Econometrica, 50, 987-1008. https://doi.org/10.2307/1912773

Fama, E. F. (1970). Efficient Capital Markets a Review of Theory and Empirical Work. The Journal of Finance, 25, 384-417. https://doi.org/10.2307/2325486

Garbade, K. D., \& Silber, W. L. (1983). Price Movements and Price Discovery in Futures and Cash Markets. The Review of Economics and Statistics, 65, 289-297. https://doi.org/10.2307/1924495

Gupta, S., Choudhary, H., \& Agarwal, D. R. (2018). An Empirical Analysis of Market Efficiency and Price Discovery in Indian Commodity Market. Global Business Review, 19, 771-789. https://doi.org/10.1177/0972150917713882

Inani, S. K. (2016). Price Discovery in the Indian Commodity Market. International Journal of Business and Emerging Markets, 8, 361-382. https://doi.org/10.1504/IJBEM.2016.079787

Kavussanos, M. G., \& Alexakis, P. D. (2008). The Lead Lag Relationship between Cash and Stock Index Futures in a New Market. European Financial Management, 14, 1007-1025. https://doi.org/10.1111/j.1468-036X.2007.00412.x

Kirithiga, S., Naresh, G., \& Thiyagarajan, S. (2018). Bullion Futures Affect Spot Prices in India. International Journal of Business Excellence, 14, 319-338. https://doi.org/10.1504/IJBEX.2018.089794

Kumar, R. (2017). Price Discovery in Some Primary Commodity Markets in India. Economics Bulletin, 37, 1817-1829.

Lehmann, B. N. (2002). Some Desiderata for the Measurement of Price Discovery across Markets. Journal of Financial Markets, 5, 259-276. https://doi.org/10.1016/S1386-4181(02)00025-3

Narayan, P. K., \& Sharma, S. S. (2018). An Analysis of Time-Varying Commodity Market Price Discovery. International Review of Financial Analysis, 57, 122-133. https://doi.org/10.1016/j.irfa.2018.03.008

Nath, G., Dalvi, M., Pawaskar, V., Rajaram, S., \& Pacheco, M. (2019). An Empirical Analysis of Efficiency in the Indian Gold Futures Market. Macroeconomics and Finance in Emerging Market Economies, 12, 240-269. https://doi.org/10.1080/17520843.2019.1604556

Pindyck, R. S. (2004). Volatility and Commodity Price Dynamics. Journal of Futures Markets, 24, 1029-1047. https://doi.org/10.1002/fut.20120

Quan, J. (1992). Two Step Testing Procedure for Price Discovery Role of Futures Prices. The Journal of Futures Markets, 12, 139-149. https://doi.org/10.1002/fut.3990120203

Rajib, P., \& Barai, P. (2021). How Futures Market in India Has Improved Efficiency of Physical Commodity Markets: An Empirical and Survey-Based Study on Aluminium and Zinc.

Schreiber, P. S., \& Schwartz, R. A. (1986). Price Discovery in Securities Markets. The Journal of Portfolio Management Summer, 12, 43-48. https://doi.org/10.3905/jpm.1986.409071

Sinha, P., \& Mathur, K. (2013). Munich Personal RePEc Archive: A Study on the Price Behavior of Base Metals traded in India. 
Stroll, H. R., \& Whaley, R. E. (1990). The Dynamics of Stock Index and Stock Index Futures Returns. Journal of Financial and Quantitative Analysis, 25, 441-468.

https://doi.org/10.2307/2331010

Tse et al. (2000). Hedging Downside Risk with Futures Contracts. Applied Financial Economics, 10, 163-170. https://doi.org/10.1080/096031000331798

Wahab, M., \& Lashgari, M. (1993). Price Dynamics and Error Correction in Stock Index and Stock Index Future Markets a Cointegration Approach. Journal of Futures Markets, 13, 711-742. https://doi.org/10.1002/fut.3990130702 